\title{
CONSUMER AND RETAIL PERCEPTIONS OF PRODUCT FAILURE: WHO IS RESPONSIBLE?*
}

\author{
G.G. ROUSSEAU \\ Department of Industrial and Organizational Psychology \\ University of Port Elizabeth
}

\begin{abstract}
The purpose of this study was to compare consumers' and retailers' perceptions of product failure in particular types of product categories. An hypothesis relating to discrepancies between consumers and retailers with regard to causes of product failure, locus of blame. and actions for preventing recurrances was proposed and empirically tested. Data were gathered from a systematic random sample of 120 consumers and 60 retailers. Complaints about products recently bought by subjects in the sample were analysed to determine how commonly products fail. Results imply that perceptual differences may occur regarding consumers' and retailers' explanations for product failure, indicating possible areas of consumer frustration. Complaints analysed identified household appliances as a major failure category.
\end{abstract}

\section{OPSOMMING}

Die doel van hierdie studie is om verbruikers en kleinhandelaars se waarnemings van produkmislukking in geval van spesifieke produk kategorieë te vergelyk. 'n Hipotese dat verskille wel bestaan tussen die waarnemings van verbruikers en kleinhandelaars ten opsigte van oorsake vir produkmislukking, bron van blaam en voorkomende optrede word gestel en empiries getoets. Data is verkry d.m.v. in sistematiese ewekansige steekproef met 120 verbruikers en 60 kleinhandelaars. As deel van die studie is klagtes oor produkte onlangs aangekoop deur proefpersone in die steekproef betrek, ontleed. Resultate impliseer dat waarnemingsverskille mag voorkom m.b.t. verbruikers en kleinhandelaars se verduidelikings vir produkmislukking. Dit kan moontlike areas van verbruikersfrustrasie aandui. Klagtes ontleed deur die opname, het huishoudelike toebehore as 'n hoofkategorie vir produkmislukking geïdentifiseer.

Within the last decade, interest has developed in consumer complaining behaviour, with a central goal of predicting how consumers respond to product failure. When a new car breaks down, when a purchasor opens a package of meat and finds it spoiled, or when recently bought apparel falls apart. what does the consumer do about it?

A number of studies describe the frequency of various responses to product dissatisfaction (Resnik \& Harmon, 1983; Fornell \& Westbrook, 1984; Folkes, 1984). Apart from a formal complaint to the seller, consumer reactions include switching brands or stores or telling others about the unsatisfactory product or retailer (Richins, 1983). Engaging in negative word-of-mouth communication is generally regarded as a potentially dangerous practice to a store or company as it implies that a party other than the consumer is blamed for the product failure. Such blame, regardless of its legitimacy, often leads to negative brand, store or company image, a phenomenon most difficult to combat (Rousseau, 1986).

Many consumers fear that when they return a product the seller will disagree about where the fault lies. Consumers who expect retailers to question their responsi-

* The research on which this study was based was funded by the Human Sciences Research Council. The author thanks Sylvia Miller and Francois Wessels for valuable assistance and advice.

Requests for reprints should be addressed to G.G. Rousseau. Department of Industrial and Organizational Psychology, University of Port Elizabeth, 6000. bility for the problem therefore refrain from complaining, thus depriving management of potentially valuable product information (Day, 1982; Andreason, 1985). Despite consumers' fears, little evidence exists that retailers disagree with consumers about causes of product failure. The research presented here is an extension of previous work by Folkes and Kotsos (1986) and Rousseau (1986).

There are at least three ways in which consumers' and retailers' perceptions of product failure can disagree. First, the perceived cause of failure may differ. It may seem to be due to (a) human error, (b) material weakness or (c) mechanical/technical inefficiencies. Second, the perceived locus of blame may differ, locus referring to (a) the human element and (b) the direction of the blame. Consumers may blame retailers or manufacturers, and retailers or manufacturers may blame consumers. Third, the perceived degree of blame may differ. Consumers, for instance, may blame partially retailers and partially manufacturers, while retailers may ascribe blame in part to consumer and in part to manufacturer. An example would be where the consumer places less blame on the retailer for warranty problems in fixing a product if the product's manufacturer goes out of business than if the retailer knowingly lied about the product's warranty (Folkes \& Kotsos, 1986).

Another determinant which may relate to locus of blame is financial gain or loss, and ego involvement. Consumer-retailer discrepancies may be expected when the allocation of blame has major financial implications for each party (as in product liability cases) or when people are highly ego-involved (as when a mech- 
anic defends his own work or a consumer defends her own actions). But will discrepancies occur even when attributions do not involve financial gain or loss or when ego involvement is minimal?

Based on the work referred to earlier, scenarios of typical buying situations were created depicting product failure. These situations represented minimum financial risk or ego involvement for the respondent. The procedure further allowed consumers not only to blame retailers or manufacturers for product failure, and retailers to blame consumers or manufacturers, but also for consumers to blame other consumers i.e., the actual buyer! Research (Burger, 1981) has shown that respondents would consider blaming other consumers for mishaps if (a) chances are good that they may experience a similar situation and (b) they can deny similarity with the victim involved (i.e. "I won't do such a stupid thing myself").
Previous research on consumer and retailer perceptions of market transactions revealed a sensitivity to situations which may hamper good relationships. It showed perceptual harmony and understanding between both parties regarding their priorities and legitimate rights (Rousseau, 1986). It was therefore regarded appropriate to determine respondents views on avoiding incidents of product failure, rather than concentrating on the negative proposition of measuring degree of blame.

To compare consumers' and retailers' perceptions of product failure the following hypothesis was set. Differences exist between the perceptions of consumers and retailers regarding (a) causes of product failure, (b) locus of blame and (c) actions for preventative recurrance. A further objective of the study was to analyse complaints of respondents in the sample regarding product/service failure.

\section{METHOD}

A sample of 120 consumers participated after 125 were initially selected, using a systematic random sample. from the telephone directory of the Port Elizabeth metropolitan area. After a random start, every tenth name was selected. Questionnaires were personally administered at home after respondents agreed over the telephone to participate in the study.

The sample of retailers was chosen from five types of business establishment: car dealers, clothing retailers, furniture stores, electrical appliance outlets and roof construction companies. These types of establishments were identified from previous research as business concerns with which consumers frequently experience product/service problems (Weyers 1985, Rousseau 1986).

A systematic random sample was selected from the yellow pages in the telephone directory of the Port Elizabeth metropolitan area. Each business concern was contacted in person by the interviewer and a senior staff member completed the same questionnaire administered to the consumers. A total of 60 business concerns participated in the study.

A questionnaire involving five scenarios of product failure was used. The scenarios were developed from letters of complaint received by the Consumer Association of Port Elizabeth, the Housewive's League, letters published in the "S A Consumer" and interviews with retailers' consumer-complaint departments. The five scenarios focused on the following product categories: cars, clothing, furniture, electrical appliances and roof construction.

Respondents were requested to read through each description of either a product or service-related problem and then to indicate (a) the most likely cause of product/service failure (b) the most likely party responsible for the failure and (c) the best way of avoiding similar incidents. Respondents checked one of three or four possible responses. Space was also provided for any comments regarding each situation described. Thus both closed- and open-response questions were used to obtain maximum feedback.

Retailers were instructed to base their responses on the official policy of the company regarding consumer complaints and customer relations. The questionnaire was tested in a pilot study for suitability to measure both consumers' and retailers' perceptions of product failure. Differences between consumers' and retailers' perceptions were tested for significance using chisquare analysis and Cramèr's test of strength of association.

Examples of actual consumer complaints were recorded and analysed as follows. At the end of the five scenarios respondents were asked an open-ended question regarding an experience with any product or service which had failed to meet their expectations during the past year. Details regarding the name of the product/service, its cause of failure, the party responsible for failure and actions suggested for avoiding similar incidents recurring in future, were requested. 


\section{RESULTS AND DISCUSSION}

\section{Perceptual differences}

A comparison of consumers' and retailers' perceptions of product failure for cars and electrical appliances is reflected in Table 1 . The results show significant differences between the two groups for both car break- down and video malfunctioning. Opinions seem to differ most on locus of blame in the first situation. Discrepancies were prominent for cause of failure and for avoiding future incidents in the second scenario.

TABLE 1

CONSUMER AND RETAILER PERCEPTIONS OF PRODUCT FAILURE FOR CARS AND ELECTRICAL APPLIANCES

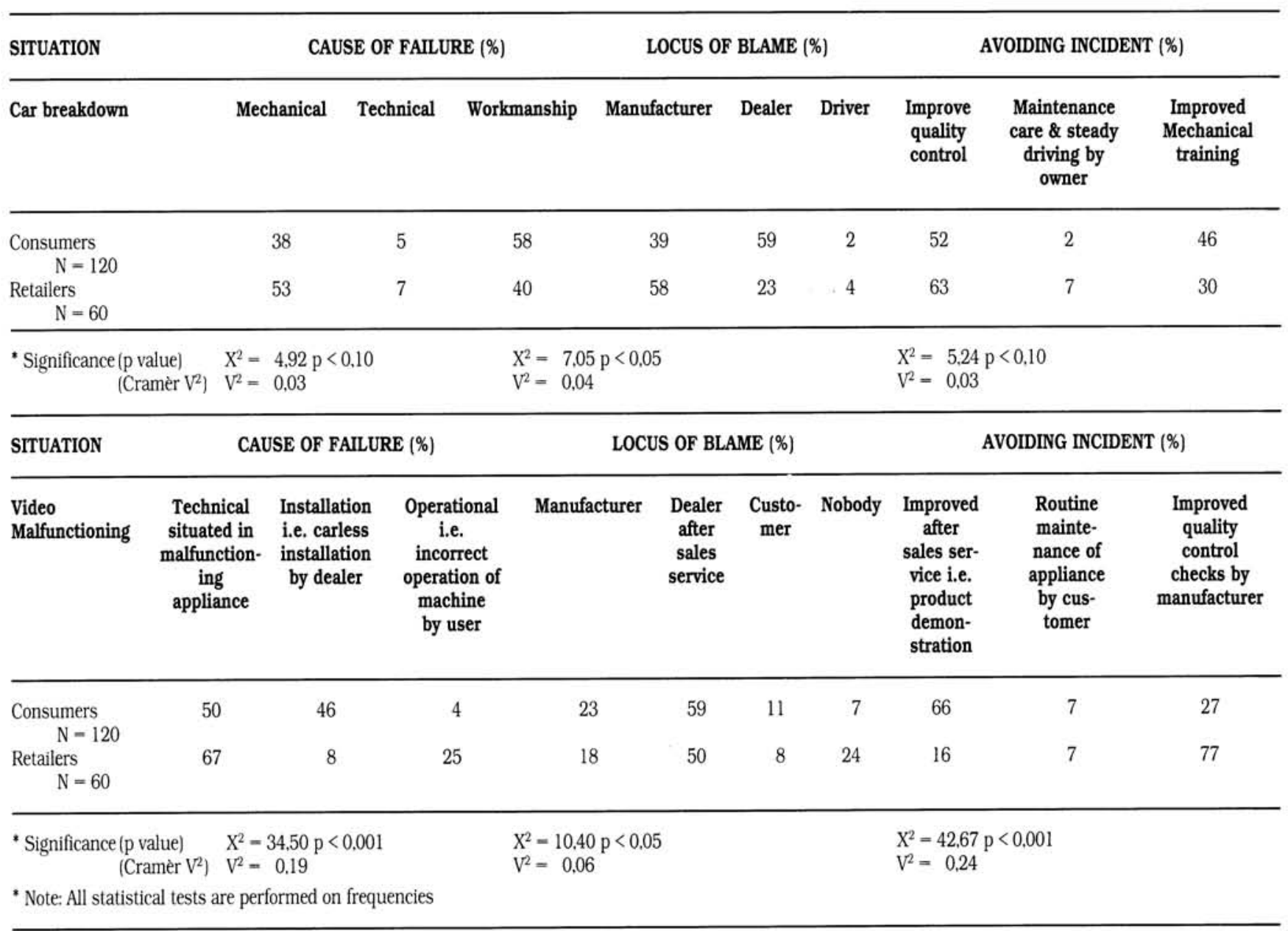

In order to investigate further the variations observed in table 1, correspondence analysis (Greenacre, 1985) was performed on these figures. Perceptual maps presented in Figures 1 and 2 illustrate the results. Consumers were more concerned with workmanship and retailers more with mechanical reasons for car break- down. Consumers pointed towards dealers while retailers blamed manufacturers for the breakdown. Retailers felt that similar incidents could be avoided by improved quality control while consumers regarded both mechanical training and quality control as important preventative measures (Figure 1).

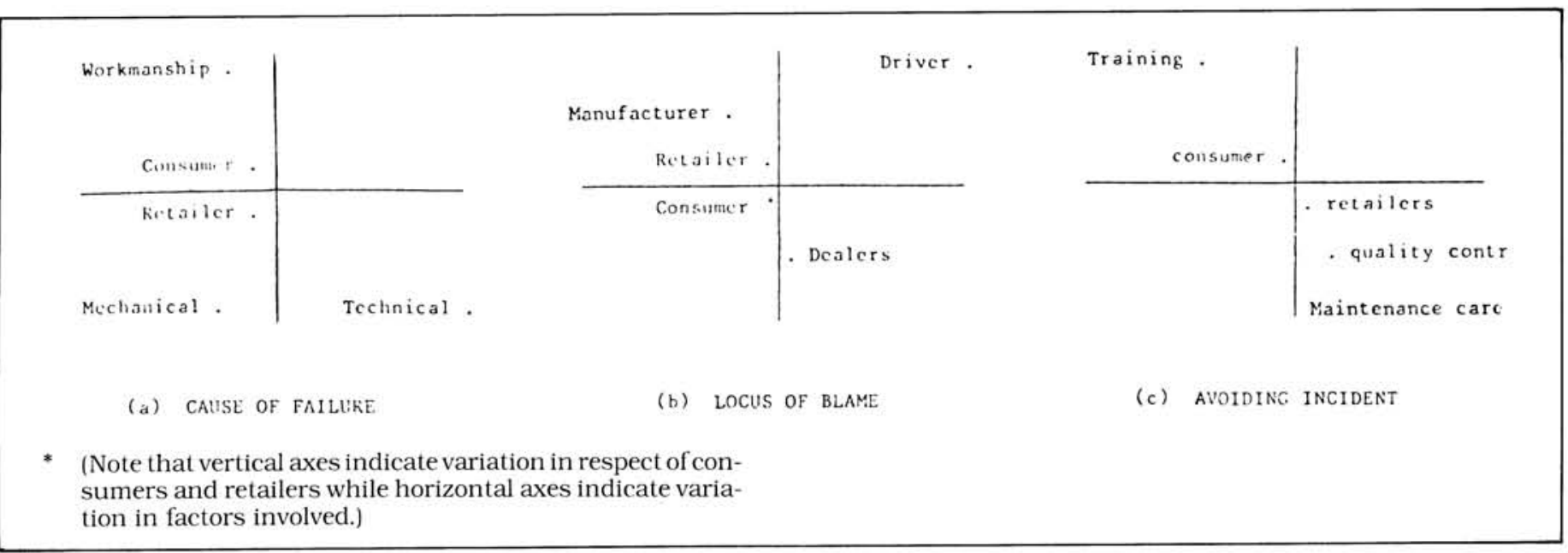




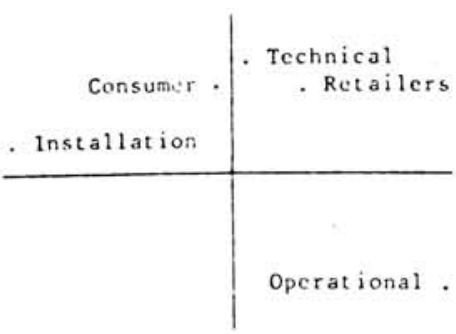

(a) CAUSE OF FAILUKC

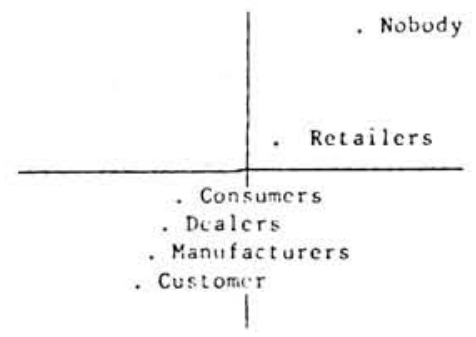

(b) LOCUS OF BLAME

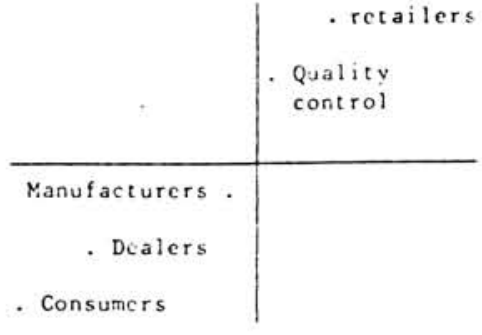

(c) AVOIDING INCIDERT

* (Note that vertical axes indicate variation in respect of consumers and retailers while horizontal axes indicate variation in factors involved.)

\section{Figure 2. Perceptual map for video malfunctioning*}

With regard to video malfunctioning, both consumers and retailers were of the opinion that technical factors were the main cause of product failure. Locus of blame identified by consumers pointed mainly towards dealers and manufacturers, while retailers also held dealers partly responsible. Consumers felt strongly that incidents of this nature should be avoided by dealers' after-sales service whilst retailers felt that quality control by manufacturers should improve.
The strength of these associations are further supported by Cràmer's V ${ }^{2}$ test shown in Table 1 .

\section{Perceptual similarities}

Results obtained for the remaining three categories of product are summarized in Table 2. Inspection of these figures clearly shows perceptual harmony between consumers and retailers.

TABLE 2

CONSUMER AND RETAILER PERCEPTIONS OF PRODUCT FAILURE FOR CLOTHING, FURNITURE AND ROOF CONSTRUCTION

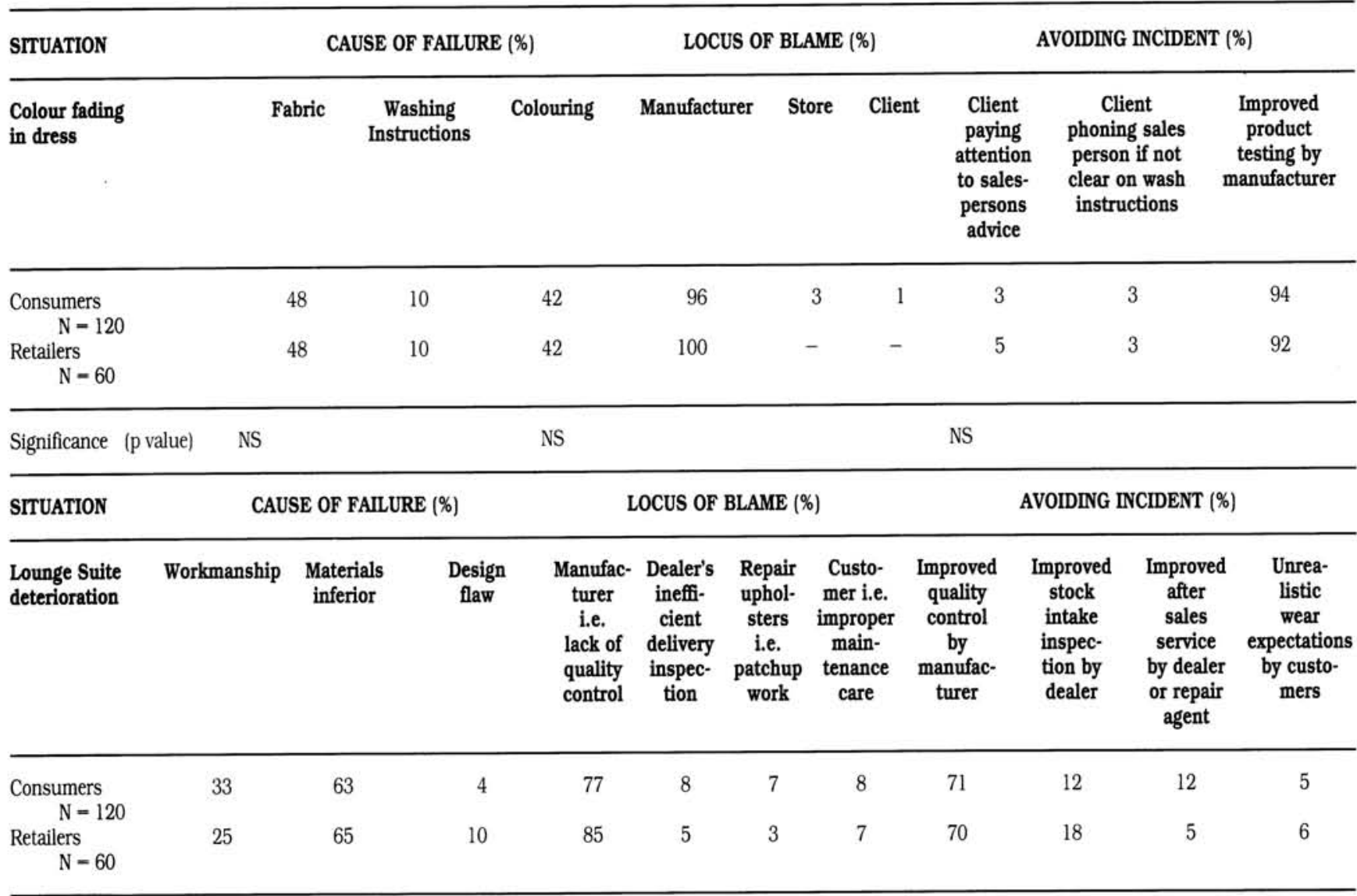




\begin{tabular}{|c|c|c|c|c|c|c|c|c|c|}
\hline \multirow{2}{*}{$\begin{array}{l}\text { SITUATION } \\
\text { Roof leakage } \\
\text { causing } \\
\text { carpet } \\
\text { damage }\end{array}$} & \multicolumn{3}{|c|}{ CAUSE OF FAILURE $(\%)$} & \multicolumn{3}{|c|}{ LOCUS OF BLAME $(\%)$} & \multicolumn{3}{|c|}{ AVOIDING INCIDENT (\%) } \\
\hline & $\begin{array}{c}\text { Roof } \\
\text { materials }\end{array}$ & $\begin{array}{l}\text { Workman- } \\
\text { ship }\end{array}$ & $\begin{array}{l}\text { Original } \\
\text { roof design } \\
\text { not suit- } \\
\text { able for } \\
\text { product }\end{array}$ & $\begin{array}{l}\text { Roof con- } \\
\text { struction } \\
\text { co. }\end{array}$ & $\begin{array}{c}\text { Home } \\
\text { owner } \\
\text { negli- } \\
\text { gence in } \\
\text { enquiring } \\
\text { about } \\
\text { quality } \\
\text { \& service }\end{array}$ & $\begin{array}{l}\text { Insu- } \\
\text { rance } \\
\text { Co. }\end{array}$ & $\begin{array}{l}\text { New after } \\
\text { sale ser- } \\
\text { vice poli- } \\
\text { cy by } \\
\text { roof con- } \\
\text { struction Co. }\end{array}$ & $\begin{array}{c}\text { Improved } \\
\text { comprehen- } \\
\text { sive pro- } \\
\text { tection by } \\
\text { insurance } \\
\text { Co. }\end{array}$ & $\begin{array}{l}\text { Improved } \\
\text { alertness } \\
\text { by consu- } \\
\text { mers to } \\
\text { protect } \\
\text { themselves }\end{array}$ \\
\hline $\begin{array}{l}\text { Consumers } \\
\qquad N=120\end{array}$ & 22 & 70 & 8 & 91 & 7 & 2 & 63 & 6 & 31 \\
\hline $\begin{array}{l}\text { Retailers } \\
\qquad N-60\end{array}$ & 17 & 72 & 11 & 90 & 8 & 2 & 65 & 5 & 30 \\
\hline
\end{tabular}

It is clear that for clothing and furniture locus of blame points mainly to the manufacturer: he is also perceived to be responsible for preventative recurrence of future incidents. It further seems obvious that both groups regard product attributes (fabric, colouring, materials) to be main causes of failure.

In the last scenario, portraying a service category, both retailers and consumers were once again in strong agreement as to cause of product failure (workmanship), locus of blame (construction company) and avoidance of future incidents (after-sales service).

Although the general hypothesis was upheld in only two of the five product/service categories tested, it is important to note that in the areas where perceptual harmony between consumers and retailers existed strong common trends emerged regarding cause of failure and locus of blame.

In the two scenarios where differences were observed consumers were more inclined to blame dealers while retailers tended to blame manufacturers. Consumers were also more sensitive towards human errors (workmanship, installation) as causes of failure while retailers tended to recognise product attributes (mechan$\mathrm{ical} /$ technical) as important

Consumers' tendency to blame retailers in many instances may be due to the fact that dealers constitute the point of contact in most purchase transactions. Consumers' lack of sensitivity to mechanical/technical failures may be due to their unfamiliarity with these issues.

\section{Complaints}

Table 3 gives data obtained from the 85 respondents who experienced product/service failure during the previous year. Although this table is self-explanatory it is interesting to note that household appliances feature prominently as a failure category. Manufacturers are held responsible for malfunctioning in almost 50 per cent of the cases. Consumers perceive improved quality control by manufacturers as a key factor for avoiding similar incidents in future.

TABLE 3

SURVEY COMPLAINTS *

PRODUCT/SERVICE CATEGORY (\%) (Percentages are based on 85 complaints received from consumer sample $\mathrm{N}=120$ )

\begin{tabular}{|c|c|c|c|c|}
\hline $\begin{array}{l}\text { Household appliances \& } \\
\text { audio-visual equipment }\end{array}$ & $\begin{array}{l}\text { Motor vehicles, } \\
\text { accessories \& parts }\end{array}$ & $\begin{array}{c}\text { Furniture } \& \\
\text { Carpets }\end{array}$ & $\begin{array}{l}\text { Clothing \& } \\
\text { Jewellery }\end{array}$ & $\begin{array}{l}\text { Building \& } \\
\text { service contracts }\end{array}$ \\
\hline 47 & 15 & 15 & 8 & 15 \\
\hline
\end{tabular}

CAUSE OF FAILURE (\%)

\begin{tabular}{|c|c|c|c|c|}
\hline Mechanical/technical & Poor quality product & $\begin{array}{l}\text { Poor quality } \\
\text { workmanship }\end{array}$ & Unknown & \\
\hline 34 & 28 & 33 & 5 & \\
\hline \multicolumn{5}{|l|}{ PARTY RESPONSIBLE (\%) } \\
\hline Manufacturer & Dealer & Repair agent & Other & \\
\hline 49 & 29 & 18 & 4 & \\
\hline \multicolumn{5}{|c|}{ AVOIDING SIMILAR INCIDENTS (\%) } \\
\hline $\begin{array}{l}\text { Improved quality control } \\
\text { by manufacturer }\end{array}$ & $\begin{array}{c}\text { Improved after- } \\
\text { sales service by } \\
\text { dealer }\end{array}$ & $\begin{array}{l}\text { Improved workman- } \\
\text { ship-supervision } \\
\text { by repair agent }\end{array}$ & $\begin{array}{l}\text { Switch brand/ } \\
\text { dealer/repair } \\
\text { agent }\end{array}$ & $\begin{array}{l}\text { Alertness by } \\
\text { customer }\end{array}$ \\
\hline 34 & 13 & 14 & 14 & 25 \\
\hline
\end{tabular}

The results of the study have important implications for manufacturers, retailers and consumers. Manufacturers sinould be encouraged to improve quality control as a means of avoiding consumer complaints. They should also support dealers in providing consumer educational programmes on product performance expectations and complaint handling.

The tendency of retailers to blame manufacturers may be explained in terms of a self-serving motivational 
bias: taking credit for good acts and denying blame for bad acts. Blaming manufacturers may provide a shortterm solution for handling complaints, but in the long run it may prove counter productive, especially when consumer investigations of serious complaints prove the opposite. Retailers should therefore deal with complaints in a responsible, fair manner, keeping the consumer's interest at heart. This would stimulate customer loyalty.

Consumers should realize that product failure may be due to a multitude of factors; it is therefore simplistic to blame only manufacturers or dealers. Instead of adopting a negative attitude to product failure, consumers should cooperate with business concerns in an unbiased manner, seeking a solution to the problem which will benefit all parties involved.

Limitations of the study should be mentioned here. As is common in most field studies, the data obtained are subject to "report error" implying that respondents' answers do not necessarily reflect their true feelings and behaviour. A further limitation is that the results reveal a serious sample omission, namely manufacturers. A more comprehensive perceptual map of product failure would have emerged had manufacturers also been included. Finally, although both closed and open ended questions were posed on the scenarios presented, it should be borne in mind that any research tool employing scripts is bound to produce situationspecific responses. More rigorous testing of the instrument developed is therefore essential to expand its applicability to other product/service categories. Apart from these limitations tentative conclusions may be drawn, as indicated above.

\section{CONCLUSION}

Despite the best efforts of manufacturers, retailers and service-providers, some consumers experience problems with products. This study has demonstrated that when products fail, consumers and retailers agree as to the issues involved in many instances. Perceptual differences may however also occur causing frustration, mistrust and undue blame among the parties involved. Retailers and manufacturers should therefore strive toward eliminating discrepant attributes for product failure by adopting an integrated approach to consumer complaints.

Perceptual discrepancies in consumer-retailer explanations for product failure were most prominent in the product categories of cars and electrical appliances while perceptual agreement was observed for clothing, furniture and roof construction. Casuality for these differences could not be explained fully on the basis of this exploratory study. Follow-up research involving a more detalled investigation is needed to interpret and support these tentative findings.

\section{REFERENCES}

Andreason, A.R. (1985). Consumer responses to dissatisfaction in loose monopolies. Journal of Consumer Research, 12, 135-141.

Burger, J.M. (1981). Motivational biases in the attributions of responsibility for an accident: A meta-analysis of the defense attribution hypothesis. Psychological Bulletin, 90, (3), 496-512.

Day, G.S. (1982). Are consumers satisfied. In Aaker, D.A. \& Day, G.S. (Eds.) Consumerism Search for the Consumers' interest (4th ed.), 403-415. New York: Free Press.
Folkes, V.S. (1984). Consumer reactions to product failure: An attributional approach. Journal of Consumer Research, 10, 398-409.

Folkes, V.S. \& Kotsos, B. (1986). Buyers' sellers explanations for product failure. Who done it? Journal of Marketing, 50, 74-80.

Fornell, C. \& Westbrook, R.A. (1984). The vicious circle of consumer complaints. Journal of Marketing, 48 , 68-78.

Greenacre, M.J. (1985). Correspondence analysis: program SIGMA (version 10) for the IBM Personal Computer. University of South Africa publication, Pretoria: Department of Statistics, UNISA.

Resnik, A.J. \& Harmon, R.R. (1983). Consumer complaints and managerial response: a holistic approach. Journal of Marketing, 47, 86-97.

Richins, M.L. (1983). Negative word-of-mouth bydissatisfied consumers: a pilot study. Journal of Marketing, 47, 68-78.

Rousseau, D. (1986). Consumer and retailer perceptions of market transactions and the complaining consumer. Proceedings of Conference for Economics, Business Economics and Manpower research, Potchefstroom: Department of Economics, University of Potchefstroom.

Rousseau, D. (1986). Good customer relations. Marketing $\mathrm{Mix}, 10,52-53$.

Van Olst, M. (1986). Complaints. The S.A. Consumer, 9, 32-33.

Weyers, J.L. (1985). Complaints. Consumer Council reports 1981-1982, 1984-1985, Pretoria. 